\title{
DNA AUTHENTICATION TECHNOLOGIES FOR PRODUCT QUALITY MONITORING IN THE WINE INDUSTRY
}

\author{
Ekaterina G. Lazareva ${ }^{1}$, Khamid Kh. Gilmanov ${ }^{1}$, Alana V. Bigaeva ${ }^{1}$, \\ Irina Yu Mikhailova ${ }^{2}$, Vladislav K. Semipyatny ${ }^{2}$, Ramil R. Vafin ${ }^{2}$ \\ ${ }^{1}$ V.M. Gorbatov Federal Research Center for Food Systems of Russian Academy of Sciences, Moscow, Russia \\ ${ }^{2}$ All-Russian Scientific Research Institute of the Brewing, Non-Alcoholic and Wine Industry - \\ Branch of the V. M. Gorbatov Federal Research Center for Food Systems of RAS, Moscow, Russia
}

\section{KEY WORDS:}

grapes, wine, marker, DNA, identification, $P C R$

\begin{abstract}
Identification of wine product authenticity is a topical question in the Russian Federation. A solution to this problem can be DNA authentication of wines, which is a technological process of product authenticity control using genetic identification of the main plant ingredient - wine grape varieties. This type of wine verification is carried out by analyzing residual amounts of Vitis vinifera L. nucleic acids extracted from cell debris of final products by molecular genetic methods. The aim of this work is the analysis of the existing methods for extraction of nucleic acids from grapes, wine raw materials and commercial wines, as well as description of the molecular genetic approaches to technical genetic identification of grape varieties and authentication of wines made from them. The obtained data suggest suitability of DNA authentication of wine products as a supplement to earlier approved analytical methods (documentary, visual, sensory, physico-chemical).
\end{abstract}

FUNDING: The article was published as part of the research topic No.0437-2019-0001 of the state assignment of the V. M. Gorbatov Federal Research Center for Food Systems of RAS

\section{Introduction}

One of the priorities in Russia over the last decade has been provision of the population with high-quality and safe food products. The alcohol industry is of great importance for economy of the Russian Federation [1]. With that, the wine industry accounts for a significant volume of manufactured products.

In Russia, wine quality is determined by several normed physico-chemical indices [2]. As the experience shows, these indices cannot guarantee the objective conclusion about wine authenticity. Due to the widespread presence of falsified products on the market, the problem of new method development became a topical issue in product quality and safety assessment. Consequently, the key task is extension of the assessment criteria area with more modern methodological base, in particular, the DNA authentication technologies.

DNA authentication of wines is a technological process of product authenticity control by genetic identification of the main plant ingredient - wine grape varieties. This type of wine verification is carried out by analyzing residual amounts of Vitis vinifera $\mathrm{L}$. nucleic acids extracted from cell debris of final products by molecular genetic methods. [3].

\section{Main part}

Analysis of the literature on residual DNA extraction from wine cell debris indicates the following key methods: Pereira [4], Savazzini \& Martinelli [5], and Nakamura [6], as well as their modifications [7]. The first two methods mentioned above have the similar extraction stage: precipitation of wine plant debris. This stage is performed using precipitators such as sodium chlo- ride, 2-propanol and sodium acetate with the following centrifugation $[4,5]$. The method for residual DNA extraction described by L. Pereira et al. [4] is most effective due to high yield of extracted residual nucleic acids (Figure 1).

Methods for DNA authentication of wine raw materials and commercial wines are based on using several genetic markers of nuclear, mitochondrial and chloroplast DNA (Table 1) [5,6].

One of the methods for DNA authentication of wine raw materials is the use of highly polymorphic DNA microsatellite loci. Initially this method was intended for genetic identification of grape varieties $[8,9,10,11,12]$. Table 2 presents the basic set for identification and certification of grape varieties and hybrids $[4,5,6,13,14,15,16,17,18,19,20]$.

The SSR fragments were amplified by multiplex PCR, which enabled combining several analyzed loci. It is conventional to use this amplification algorithm when working with DNA obtained from grape plant parts (fruit, leaf, stem, root); however, it is not efficient when analyzing the extracted residual nucleic acid from wine $[5,6,13,14,15]$.

Another type of SSR markers targeted to chloroplast DNA (spSSR) $[21,22,23,24,25]$ has several advantages compared to the analysis of nuclear DNA ( $n S S R$ ) due to the higher copy number of a target per cell, higher resistance to the exonuclease action and lower susceptibility to degradation because of its content in organelles with the double membrane $[5,7]$.

Analysis of microsatellite loci of chloroplast DNA remains to be an alternative approach to varietal genetic identification of Vitis vinifera L. as this type of SSR markers has the low discriminatory ability.

Table 1

Markers used for wine DNA authentication

Methods for DNA authentication of wine raw materials and wine products

$S S R$ - markers of nuclear, mitochondrial and chloroplast DNA of Vitis vinifera $\mathrm{L}$
STS- markers of nuclear, mitochondrial and chloroplast DNA of Vitis vinifera L
STS- markers of nuclear, mitochondrial and chloroplast DNA of Vitis vinifera L 


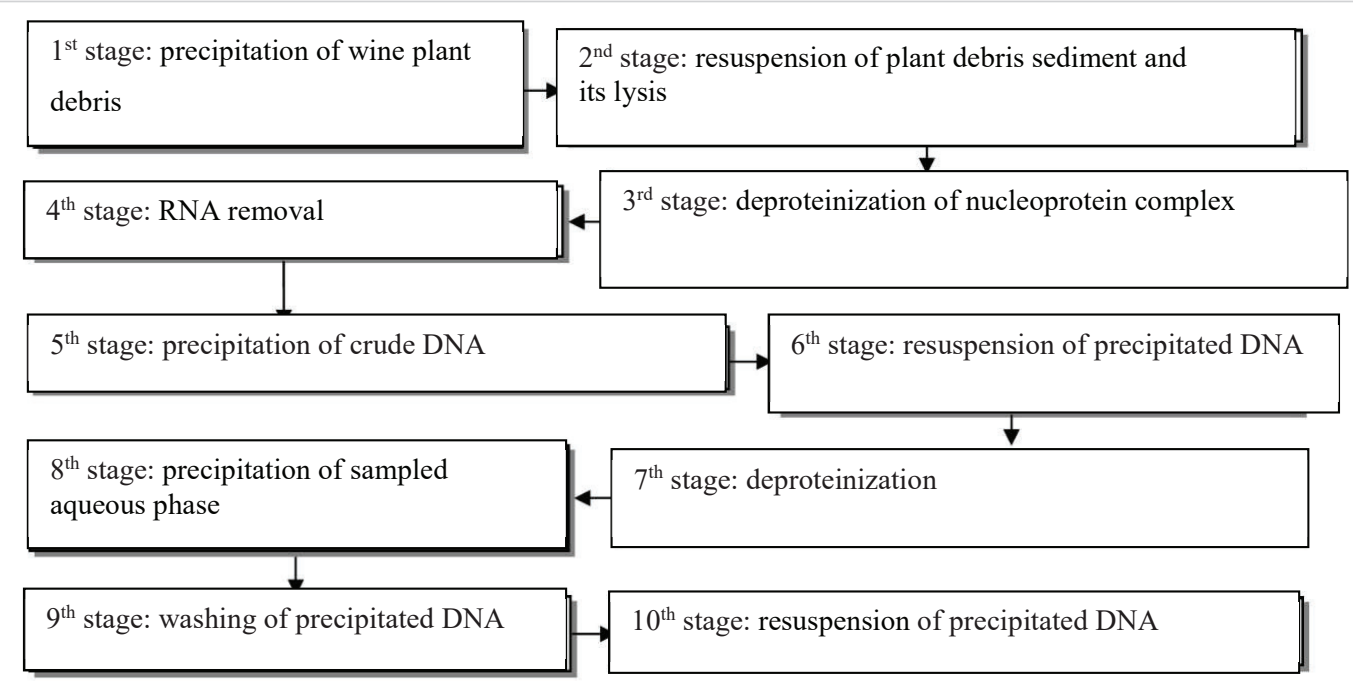

Figure 1. Stages of sample preparation and extraction of Vitis vinifera L. DNA from wine by the Pereira method

SSR markers of nuclear DNA used for large-scale identification and certification of grape varieties and hybrids partly suitable for DNA authentication of wines

\begin{tabular}{|c|c|c|c|}
\hline No & SSR locus & Sequence of oligonucleotide primers & Range of allele lengths, bp \\
\hline \multirow{2}{*}{1} & \multirow{2}{*}{ VVS2 } & 5/-CAGCCCGTAAATGTATCCATC-3/ & \multirow{2}{*}{$123-165$} \\
\hline & & 5/-AAATTCAAAATTCTAATTCAACTGG-3/ & \\
\hline \multirow{2}{*}{2} & \multirow{2}{*}{ VVMD5 } & 5/-CTAGAGCTACGCCAATCCAA-3' & \multirow{2}{*}{$220-268$} \\
\hline & & 5/-TATACCAAAAATCATATTCCTAAA-3/ & \\
\hline \multirow{2}{*}{3} & \multirow{2}{*}{ VVMD7 } & 5/AGAGTTGCGGAGAACAGGAT-3/ & \multirow{2}{*}{$231-267$} \\
\hline & & 5/-CGAACCTTCACACGCTTGAT-3/ & \\
\hline \multirow{2}{*}{4} & \multirow{2}{*}{ VVMD25 } & 5/-TTCCGTTAAAGCAAAAGAAAAAGG-3' & \multirow{2}{*}{$243-275$} \\
\hline & & 5/-TTGGATTTGAAATTTATTGAGGGG-3/ & \\
\hline \multirow{2}{*}{5} & \multirow{2}{*}{ VVMD27 } & 5/-GTACCAGATCTGAATACATCCGTAAGT-3/ & \multirow{2}{*}{$173-223$} \\
\hline & & 5/-ACGGGTATAGAGCAAACGGTGT-3' & \\
\hline \multirow{2}{*}{6} & \multirow{2}{*}{ VVMD28 } & 5/-AACAATTCAATGAAAAGAGAGAGAGAGA-3/ & \multirow{2}{*}{$216-285$} \\
\hline & & 5/-TCATCAATTTCGTATCTCTATTTGCTG-3' & \\
\hline \multirow{2}{*}{7} & \multirow{2}{*}{ VVMD32 } & 5/-TATGATTTTTTAGGGGGGTGAGG-3/ & \multirow{2}{*}{$234-272$} \\
\hline & & 5/-GGAAAGATGGGATGACTCGC-3/ & \\
\hline \multirow[b]{2}{*}{8} & \multirow{2}{*}{ VrZAG62 } & 5/-GGTGAAATGGGCACCGAACACACGC-3/ & \multirow{2}{*}{$173-219$} \\
\hline & & 5/-CCATGTCTCTCCTCAGCTTCTCAGC-3/ & \\
\hline 9 & VrZAG79 & 5/-AGATTGTGGAGGAGGGAACAAACCG-3/ & $236-270$ \\
\hline
\end{tabular}

The use of microsatellite DNA as a source of STS is also mentioned in the literature. Sequence Tagged Site (STS) is a short unique sequence, which amplified profiles serve as molecular genetic markers [4, 13]. For example, S. Nakamura et al. (2007) [6] developed the experimental STS primer sets for certain SSR loci of mitochondrial and chloroplast DNA [10, 21] and tested them in PCR for identification of Vitis vinifera L. varieties, as well as DNA authentication of wines produced from them.

As for SNP markers [26], they are also suitable for DNA authentication of wines [12]. SNP markers have the following advantages:

$\square$ differentiation of individual Vitis vinifera L. genotypes in single-varietal wines and assemblage wines with the possibility of quantitative assessment of plant ingredients

$\square$ efficiency in the analysis of the fragmented DNA of low quality.

Table 3 presents the primer and probe sets for real-time PCR with fluorescent hybridization detection, which are used in ge- netic identification of the Sangiovese variety and DNA authentication of wine produced from it by the single-nucleotide polymorphism (SNP) analysis in three analytical positions (98, 222 and 244) [7].

Another variant for application of SNP markers is to use the knowledge about single nucleotide polymorphism in several genes of Vitis vinifera L. incorporated into the method for highresolution melting $(H R M)$ curve analysis based on the real-time PCR platforms [12, 26, 27].

$H R M$ analysis is an effective genotyping technology [28,29] with combined PCR stages and highly specific and sensitive detection with a possibility to differentiate several genotypes within one analysis, which is also suitable for wine DNA authentication $[12,26]$.

\section{Conclusion}

Analysis of methods for extraction of residual nucleic acids from final alcoholic products indicates the topicality and prospects of using DNA authentication as a molecular genetic 
method for controlling safety of alcoholic beverages and detecting adulteration. The use of DNA technologies facilitates the most reliable determination of product authenticity in the wine industry. Molecular marker systems are suitable for identification of wine grape (Vitis vinifera L.) varieties and can ensure traceability throughout the life cycle of a final product.

Real-time PCR primers and probes for three SNP positions applied in genetic identification of the Sangiovese variety and DNA authentication of wine produced from it

\begin{tabular}{|c|c|c|c|}
\hline SNP & PPCR Round & Oligonucleotide primers and TaqMan probes & PCR product \\
\hline \multirow[b]{2}{*}{98} & $1^{\text {st }}$ PCR round with external primers & $\begin{array}{l}\text { 5/-TTCAAAGCGAAGAACCAG-3/ } \\
\text { 5/-ACCCTTCAACAAACCAAC-3/ }\end{array}$ & $790 \mathrm{bp}$ \\
\hline & $\begin{array}{l}2^{\text {nd }} \text { PCR round with nested primers } \\
\text { and TaqMan probes }\end{array}$ & $\begin{array}{l}\text { 5/-GTTAGTGTAAGGTGATGCC-3/ } \\
\text { 5/-TTTCCTAATCCTTGTTGG-3/ } \\
\text { 5/-FAM-TAGGATTTATGAAGGGAAG-3/-BHQ1 } \\
\text { 5/-VIC-TAGGATTTATGAAGGCAAG-3/-BHQ2 }\end{array}$ & $136 \mathrm{bp}$ \\
\hline \multirow[b]{2}{*}{222} & $1^{\text {st }}$ PCR round with external primers & $\begin{array}{l}\text { 5/-AGACTGACTTTTGAAACACC-3/ } \\
\text { 5/-TTCCTGGATTGGGTATG-3/ }\end{array}$ & 889 bp \\
\hline & $\begin{array}{l}2^{\text {nd }} \text { PCR round with nested primers } \\
\text { and TaqMan probes }\end{array}$ & $\begin{array}{l}\text { 5/-AAGACACCCACCAAGTTC-3/ } \\
\text { 5/-CCAGGCAAGTAACACAAG-3/ } \\
\text { 5/-FAM-AGCAATGTGGGCTGA-3/-BHQ1 } \\
\text { 5/-VIC-AGCAATGTGGGCCGA-3/-BHQ2 }\end{array}$ & $128 \mathrm{bp}$ \\
\hline \multirow[b]{2}{*}{244} & $1^{\text {st }}$ PCR round with external primers & $\begin{array}{l}\text { 5/-AAACGCAGGAGAATGTC-3/ } \\
\text { 5/-TTCAACCTGATGCCTAAC-3/ }\end{array}$ & $721 \mathrm{bp}$ \\
\hline & $\begin{array}{l}2^{\text {nd }} \text { PCR round with nested primers } \\
\text { and TaqMan probes }\end{array}$ & $\begin{array}{l}\text { 5/-AATCCCCATCCCGAAGTG-3/ } \\
\text { 5/-CCCAGTTCCATTCCTACACC-3/ } \\
\text { 5/-FAM-CCTTTCTGGGTTGAACA-3/-BHQ1 } \\
\text { 5/-VIC-CCTTTCTGGGTTGCACA-3/-BHQ2 }\end{array}$ & $136 \mathrm{bp}$ \\
\hline
\end{tabular}

\section{REFERENCES}

1. Oganesyants, L.A., Khurshudyan, S.A., Galstyan, A.G. (2018). Food quality monitoring as the basic strategic element. Production Quality Control, 4, 56-59. (In Russian)

2. Parkhomenko, A.I. (2016). Identification and detection of wine falsifications for customs purposes. Education and Science Without Borders: Social Sciences and Humanities, 3, 298-301. (In Russian)

3. Oganesyants, L.A., Vafin, R.R., Galstyan, A.G., Semipyatniy, V.K., Khurshudyan, S.A., Ryabova, A.E. (2018). Prospects for DNA authentication in wine production monitoring. Foods and Raw Materials. 6(2), 438448. https://doi.org/10.21603/2308-4057-2018-2-438-448

4. Pereira, L., Guedes-Pinto, H., Martins-Lopes, P. (2011). An enhanced method for vitis vinifera L. DNA extraction from wines. American Journal of Enology and Viticulture, 62(4), 547-552. https://doi.org/10.5344/ ajev.2011.10022

5. Savazzini, F., Martinelli, L. (2006). Development of methods for enhanced extraction and real-time polymerase chain reaction quantification. Analytica Chimica Acta, 536(1-2), 274-282. https://doi.org/10.1016/j. aca.2005.10.078

6. Nakamura, S., Haraguchi, K., Mitani, N., Ohtsubo, K. (2007). Novel preparation method of template DNAs from wine for PCR to differentiate grape (Vitis vinifera L.) cultivar. Journal of Agricultural and Food Chemistry, 55(25), 10388-10395. https://doi.org/10.1021/jf072407u

7. Catalano, V., Moreno-Sanz, P., Lorenzi, S., Grando, M.S. (2016). Experimental Review of DNA-Based Methods for Wine Traceability and Development of a Single-Nucleotide Polymorphism (SNP) Genotyping Assay for Ouantitative Varietal Authentication. Journal of Agricultural and Food Chemistry, 64(37), 6969-6984. https://doi.org/10.1021/acs.jafc.6b02560

8. Thomas, M.R., Scott, N.S. (1993). Microsatellite repeats in grapevine reveal DNA polymorphisms when analysed as sequence-tagged sites (STSs). Theoretical and Applied Genetics, 86(8), 985-990. https://doi. org/10.1007/BF00211051

9. Bowers, J.E., Dangl, G.S., Vignani, R., Meredith, C.P. (1996). Isolation and characterization of new polymorphic simple sequence repeat loci in grape (Vitis vinifera L.). Genome, 39(4), 628-633. https://doi.org/10.1139/g96-080

10. Sefc, K.M., Regner, F., Turetschek, E., Glössl, J., Steinkellner, H. (1999). Identification of microsatellite sequences in Vitis riparia and their applicability for genotyping of different Vitis species. Genome, 42(3), 367-373. https://doi.org/10.1139/g98-168

11. Maul, E., Töpfer, R., Carka, F., Cornea, V., Crespan, M., Dallakyan, M., de Andrés Domínguez, T., de Lorenzis, G., Dejeu, L., Goryslavets, S., Grando, S., Hovannisyan, N., Hudcovicova, M., Hvarleva, T., Ibáñez, J., Kiss, E., Kocsis, L., Lacombe, T., Laucou, V., Maghradze, D., Maletić, E., Melyan, G., Mihaljević, M.Z., Muñoz-Organero, G., Musayev, M., Nebish, A., Popescu, C.F., Regner, F., Risovanna, V., Ruisa, S., Salimov, V., Savin, G., Schneider, A., Stajner, N., Ujmajuridze, L., Failla, O. (2015). Identification and characterization of grapevine genetic resources maintained in Eastern European Collections. Journal of Grapevine Research, 54, 5-12.

12. This, P., Jung, A., Boccacci, P., Borrego, J., Botta, R., Costantini, L., Crespan, M., Dangl, G.S., Eisenheld, C., Ferreira-Monteiro, F., Grando, S.,
Ibáñez, J., Lacombe, T., Laucou, V., Magalhães, R., Meredith, C.P., Milani, N., Peterlunger, E., Regner, F., Zulini, L., Maul, E. (2004). Development of a standard set of microsatellite reference alleles for identification of grape cultivars. Theoretical and Applied Genetics, 109(7), 1448-1458. https://doi.org/10.1007/s00122-004-1760-3

13. Drábek, J., Stávek, J., Jalvková, M., Jurcek, T., Frébort, I. (2008). Quantification of DNA during winemaking by fluorimetry and Vitis vinifera L.-specific quantitative PCR. European Food Research and Technology, 226(3), 491-497. https://doi.org/10.1007/s00217-007-0561-8

14. Bigliazzi, J., Scali, M., Paolucci, E., Cresti, M., Vignani, R. (2012). DNA extracted with optimized protocols can be genotyped to reconstruct the varietal composition of monovarietal wines. American Journal of Enology and Viticulture, 63(4), 568-573. https://doi.org/10.5344/ ajev.2012.12014

15. Rodríguez-Plaza, P., González, R., Moreno-Arribas, M.V., Polo, M.C Bravo, G., Martínez-Zapater, J.M., Martínez, M.C., Cifuentes, A. (2006). Combining microsatellite markers and capillary gel electrophoresis with laser-induced fluorescence to identify the grape (Vitis vinifera) variety of musts. European Food Research and Technology, 223(5), 625-631. https://doi.org/10.1007/s00217-005-0244-2

16. Siret, R., Gigaud, O., Rosec, J.P., This, P. (2002). Analysis of grape Vitis vinifera L. DNA in must mixtures and experimental mixed wines using microsatellite markers. Journal of Agricultural and Food Chemistry, 50(13), 3822-3827. https://doi.org/10.1021/jf011462e

17. Hârta, M.H., Pamfil, D., Pop, R., Vicaş, S. (2011). DNA Fingerprinting Used for Testing Some Romanian Wine Varieties. Bulletin UASVM Horticulture, 68(1), 143-148.

18. Siret, R., Boursiquot, J.M., Merle, M.H., Cabanis, J.C., This, P. (2000). Toward the authentication of varietal wines by the analysis of grape (Vitis vinifera L.) Residual DNA in must and wine using microsatellite markers. Journal of Agricultural and Food Chemistry, 48(10), 5035-5040. https://doi. org/10.1021/jf991168a

19. Boccacci, P., Akkak, A.. Marinoni, D. T. Gerbi, V., Schneider, A. (2012). Genetic traceability of Asti Spumante and Moscato d'Asti musts and wines using nuclear and chloroplast microsatellite markers. European Food Research and Technology, 235(3),439-446. https://doi.org/10.1007/ s00217-012-1770-3

20. Pereira, L., Martins-Lopes, P., Batista, C., Zanol, G.C., Clímaco, P., Brazão, J., Eiras-Dias, J.E., Guedes-Pinto, H. (2012). Molecular Markers for Assessing Must Varietal Origin. Food Analytical Methods, 5(6), 1252-1259. https://doi.org/10.1007/s12161-012-9369-7

21. Scali, M., Elisa, P., Jacopo, B., Mauro, C., Vignani, R. (2014). Vineyards genetic monitoring and Vernaccia di San Gimignano wine molecular fingerprinting. Advances in Bioscience and Biotechnology, 5(2), 142-154. https://doi.org/10.4236/abb.2014.52018

22. Chung, S.-M., Staub, J.E. (2003). The development and evaluation of consensus chloroplast primer pairs that possess highly variable sequence regions in a diverse array of plant taxa. Theoretical and Applied Genetics, 107(4), 757-767. https://doi.org/10.1007/s00122-003-1311-3 
23. Weising, K., Gardner, R.C. (1999). A set of conserved PCR primers for the analysis of simple sequence repeat polymorphisms in chloroplast genomes of dicotyledonous angiosperms. Genome, 42(1), 9-19. https://doi. org/10.1139/g98-104

24. Arroyo-García, R., Lefort, F., de Andre's, M.T., Ibañez, J., Borrego, J. Jouve, N., Cabello, F., Martı'nez-Zapater, J.M. (2002). Chloroplast microsatellite polymorphisms in Vitis species. Genome, 45(6), 1142-1149. https://doi.org/10.1139/g02-087

25. Ebert, D., Peakall, R. (2009). Chloroplast simple sequence repeats (cpSSRs): technical resources and recommendations for expanding cpSSR discovery and applications to a wide array of plant species. $\mathrm{Mo}$ lecular Ecology Resources, 9(3), 673-690. https://doi.org/10.1111/j.17550998.2008.02319.x

26. Lijavetzky, D., Cabezas, J.A., Ibáñez, A., Rodríguez, V., Martínez-Zapater, J.M. (2007). High throughput SNP discovery and genotyping in grapevine (Vitis vinifera L.) by combining a re-sequencing approach and SNPlex technology. BMC Genomics, 8, 424. https://doi.org/10.1186/14712164-8-424

27. Gomes, S., Castro, C., Barrias, S., Pereira, L., Jorge, P., Fernandes, J.R., Martins-Lopes. P. (2018). Alternative SNP detection platforms, HRM and biosensors, for varietal identification in Vitis vinifera L. using F3H and LDOX genes. Scientific Reports, 8(1), 5850. https://doi.org/10.1038/ s41598-018-24158-9

28. Kurbakov, K.A., Konorov, E.A., Minaev, M. Yu., Kuznetsova, O.A. (2019) Multiplex real-time PCR with HRM for detection of Lactobacillus sakei and Lactobacillus curvatus in Food Samples. Food Technology and Biotechnology, 57(1), 97-104. https://doi.org/10.17113/ftb.57.01.19.5983

29. Druml, B., Cichna-Markl, M. (2014). High resolution melting (HRM) analysis of DNA - Its role and potential in food analysis. Food Chemistry, 158, 245-254. https://doi.org/10.1016/j.foodchem.2014.02.111

\section{AUTHOR INFORMATION}

Ekaterina G. Lazareva - Junior research scientist, Laboratory of Molecular Biology and Bioinformatics, V. M. Gorbatov Federal Research Center for Food Systems of RAS. 109316, Moscow, Talalikhina str., 26. Tel.: +7-499-245-61-18. E-mail: lkg1996@mail.ru ORCID: https://orcid.org/0000-0002-8069-9661

*corresponding author

Khamid Kh. Gilmanov - Candidate of biological sciences, Staff Scientist, Laboratory of Molecular Biology and Bioinformatics, V. M. Gorbatov Federal Research Center for Food Systems of RAS. 109316, Moscow, Talalikhina str., 26. Tel.: +7-499-245-61-18. E-mail: gilmanov.xx@mail.ru ORCID: https://orcid.org/0000-0001-8400-2465

Alana V. Bigaeva - Staff Scientist, Laboratory of Molecular Biology and Bioinformatics, V. M. Gorbatov Federal Research Center for Food Systems of RAS. 109316, Moscow, Talalikhina str., 26. Tel.: +7-499-245-61-18. E-mail: ada14-5@yandex.ru

ORCID: https://orcid.org/0000-0001-7053-6925

Irina Yu. Mikhailova - Scientist, Interdisciplinary scientific and technical center of food quality monitoring, All-Russian Scientific Research Institute of Brewing, Beverage and Wine Industry - Branch of V. M. Gorbatov Federal Research Center for Food Systems of RAS. 119021 , Moscow, Rossolimo str., 7. Tel.: +7-499-245-61-18. E-mail:vogts-villa@mail.ru ORCID: https://orcid.org/0000-0003-0514-505X

Vladislav K. Semipyatny - Candidate of technical sciences, Senior research scientist, Interdisciplinary scientific and technical center of food quality monitoring, All-Russian Scientific Research Institute of Brewing, Beverage and Wine Industry - Branch of V. M. Gorbatov Federal Research Center for Food Systems of RAS. 119021, Moscow, Rossolimo str., 7. Tel.: +7-499-245-61-18, E-mail: semipyatniy@gmail.com ORCID: https://orcid.org/0000-0003-1241-0026

Ramil R. Vafin - Doctor of Biological Sciences, Professor of RAS, leading scientistct, Interdisciplinary scientific and technical center of food quality monitoring, All-Russian Scientific Research Institute of Brewing, Beverage and Wine Industry - Branch of V. M. Gorbatov Federal Research Center for Food Systems of RAS. 119021, Moscow, Rossolimo str., 7. Tel.: +7-499-245-61-18. E-mail: vafin-ramil@mail.ru ORCID: https://orcid.org/0000-0003-0914-0053

All authors bear responsibility for the work and presented data.

All authors made an equal contribution to the work.

The authors were equally involved in writing the manuscript and bear the equal responsibility for plagiarism.

The authors declare no conflict of interest.

Received 04.11.2020 Accepted in revised 02.12.2020 Accepted for publication 22.12.2020 